\title{
General Editors' Preface
}

We present in this volume the first four of five parts in Bernard Lonergan's De Verbo incarnato. The fifth part, which devotes three theses $\left(15^{-17}\right)$ to the theme of redemption, will be incorporated into volume 9 , which will also include the complete text, with English translation, of a previously unpublished supplement to De Verbo incarnata, 'De redemptione.'

In his 'General Editors' Preface' to volume 7 in Collected Works of Bernard Lonergan, The Ontological and Psychological Constitution of Christ, Frederick E. Crowe wrote, 'The full history of Lonergan's work in Christology (courses, writings, occasional lectures) will be more appropriately given in the preface to volume 8 of the Collected Works.' But the history of Lonergan's engagement with Christology has since been much more amply documented in Crowe's 2005 book Christ and History. ${ }^{1}$ We can happily now send readers to that book for the detailed history.

The most relevant information for our present purposes has to do with Lonergan's teaching. He taught courses on Christology many times: at the Jesuit Seminary in Toronto (now Regis College) in 1948-49 and 1952-53, at the Gregorian University in Rome in 1953-54, 1955-56, 1957-58, 1959-60, 1961-62, 1963-64, and 1964-65, and at the Divinity School, Harvard University, in 1971-72. He began a course in Christology at Regis College in

1 Frederick E. Crowe, s.J., Christ and History: The Christology of Bernard Lonergan from I935 to I982 (Ottawa: Novalis, 2005). Reprinted by University of Toronto Press, 2015. 
1972-73, but for health reasons was not able to complete it; Crowe completed the course for him.

It is likely that Lonergan's first Christological text in connection with his courses was 'De conscientia Christi,' an eight-page set of notes produced at Regis in 1952. It has been published in vol. 19 of the Collected Works, Early Latin Theology. Its content is very different from the treatment accorded the consciousness of Christ in De constitutione Christi and De Verbo incarnato. The contrast provides interesting data on his development.

His next Christological work, 'De ratione convenientiae eiusque radice ...,' consisted of twelve legal-size pages produced at the Gregorian in connection with his course of 1953-54. It also is now part of vol. 19 in the Collected Works.

De constitutione Christi ontologica et psychologica, now available as the previously mentioned vol. 7 in the Collected Works, was issued at the Gregorian in 1956, with reprints in 1958, 1961, and 1964. And De Verbo incarnato was published at the Gregorian in 1960, with new editions in 1961 (in content almost identical with the 1960 volume) and 1964 . The 1964 volume contains a completely new and revised thesis on the knowledge of Christ, arguably Lonergan's greatest contribution to Christology. The present volume includes also the earlier version of this thesis in appendix 2.

It was probably in 1958 that Lonergan drafted the bulk of another work, which he thought of as a supplement to De Verbo incarnato. It was never published, but as mentioned above it will appear in volume 9 of the Collected Works. His course at Harvard was recorded, as was the beginning of his course at Regis in 1973; the recordings are available on the website www.bernardlonergan.com.

The four parts of the present volume treat, respectively, 'The Teaching of the New Testament on the Hypostatic Union,' 'The Teaching of the Ecumenical Councils on the Hypostatic Union,' 'Theological Conclusions regarding the Hypostatic Union,' and 'What Belongs Properly to Christ.' Some might justifiably regard the title of part 1 as anachronistic, but it is found as such in Lonergan's text; 'Biblical Bases of Christological Dogma' would perhaps have been a more accurate title.

Original suggestions and contributions can be found in each part: the notion of schematic patterns in part 1, part 2's elegant presentation of an example of work in what would come to be called the functional specialty 'Doctrines,' part 3's proposals regarding the secondary act of existence and especially regarding the consciousness of Christ, and part 4's theses on the knowledge of Christ (thesis 12) and on Christ's freedom (thesis 14). De- 
spite its obvious appearance and function as a textbook or even a manual, the volume contains some points that may well remain permanently valid theological contributions. I would claim this status in particular for the contributions on the consciousness and knowledge of Christ.

The Collected Works edition has been eagerly awaited by many students of Lonergan, and we are happy to be able to make it available. The final product is the work of many hands, but as General Editor I take responsibility, for better or for worse, for adjudicating the various contributions. Five individual contributions demand attention, along with an institutional source of assistance.

First, and above all, I wish to thank Charles Hefling for his extremely careful and precise translation of the text, as well as for his supreme patience as the slow process of publishing the Collected Works has gone forward and the editing of the present volume has proceeded

Next, I owe a large debt of gratitude to Jeremy Wilkins for his scrupulously expert contributions to editing both the English and the Latin texts. This is a much better volume than it would have been had I been the sole editor.

Third, Eric Mabry has done a great service by adding the Tanner references (DEC) in the English text and by supplementing the Migne information with indications of critical texts where these are available.

Fourth, the two official readers appointed by University of Toronto Press, whose identity I do not know, provided extraordinary assistance in tidying up what even a very long process of editing had unwittingly left in need of further work.

And fifth, I wish to thank John St James for his extraordinary work as copy-editor, not only on this volume but also on most of the others in this series. No doubt this was one of the more difficult volumes to work on!

The Lonergan Research Institute has, of course, supported the Collected Works project for nearly thirty years, and with this volume has in particular made possible the work of Professor Wilkins. I like to take the opportunity afforded by these General Editors' Prefaces to give continued thanks to Marquette University for its support of the Marquette Lonergan Project and so for funding my work as editor not only on this volume but ever since 2006.

Lonergan did not put any footnotes in his text, and so all footnotes in the present volume are editorial. Some of them simply give greater detail to items that Lonergan included in the body of the text.

As has been our custom, we have used the New Revised Standard Version as the default translation of the Bible unless reason was found to supply 
an alternate translation. DB and DS refer to the two versions of Denzinger's Enchiridion that Lonergan employed in the 1964 version of the manuscript. In general the Oxford American Dictionary and the Chicago Manual of Style were relied on in their respective realms of authority, though not rigidly.

May this work now take its long overdue part in the total corpus of the Collected Works of Bernard Lonergan.

ROBERT M. DORAN

Marquette University 